\title{
布の好みの個人差の因果分析的研究*
}

\section{市原 茂**}

\begin{abstract}
The aim of this report is to clarify the origin of the individual differences in the results of a sensory test. In the test, the 45 subjects looked at cotton cloths of various colors and weaves, and evaluated their impressions of the cloths. The clear individual differences in the preference of cloths were observed. It was considered that the preference difference originated in the causal relationship difference between two or three impressions of the cloths. Six causal models (structural equation models) between these impressions were matched to each subject. Twenty-five subjects fitted into one of these models except one model. They were classified into five groups according to the most suitable model. Moreover, each group had a preference tendency of its own. These results support the assumption that the causal relationship between the impressions is the origin of this preference difference.
\end{abstract}

配色と織り方の異なる 105 枚の綿布を 20 の印象評定項目のそれぞれについて 7 段階評定させたと ころ, 一部の評定項目を除き個人差が非常に大きくでた。このような個人差は, 対象によって引き起 こされる印象どうしの因果的な結びつきが各個人によって異なるために生じると考えた，そこで，そ れらの印象どうしの因果モデルを 6 つ想定し, 個人ごとに共分散構造分析を実施し, 各個人がいずれ の因果モデルに適合するのかをみた. 45 名中 25 名にいずれかのモデルがあてはまった。一方, 綿布に 対する好みのデータから，45 名の被験者全員をクラスター分析により分類したところ，3つのグルー プに分かれた。これと因果分析の結果を比較したところ，両者にゅるい関係があることがわかった。 以上より, 官能検査の個人差を生む人間の感性情報処理の一部が明らかにされた。 （キーワード : 官能検査，個人差，共分散構造分析，因果モデル，配色，布）

\section{1. はじめに}

人がある対象を最終的に“良い”とか“好き”と評 価する際に，その人の内部では良いとか好き以外にも たくさんの印象が生じるはずである．たとえば“これ はさわやかだな”とか “これはずいぶんモダンだな” という具合である。ささわやかなものが好きな人はさわ やかな印象のするものを高く評価し，モダンなものが 好きな人はモダンな印象のするものを高く評価するこ とは当然であり, 評価の個人差が生じる原因はそこに あるということもできる。そして，ある対象に対する

* 1994 年 11 月 28 日受付

** 東京都立大学 人文学部

Faculty of Social Science and Humanities, Tokyo Metropolitan Univ.
高いあるいは低い評価の理由を尋ねられたときに, “自 分はモダンなものが好きだから”とか, “若々しい感じ がするものが好きだから”というように, 評価の理由 をはっきりと答えることができる人もいれば,“ただな んとなく”というように，その理由がはっきりと意識 化されていない人もいる．しかし，理由をはっきりと 言えなかった人でも, ある対象に対して最終的な評価 を下すためには，なんらかの理由があったはずである. このように最終的な評価へと至る道筋が意識化され ていない場合にも，その道筋を明らかにする手段とし て, 共分散構造分析による因果分析 ${ }^{1)}$ はひとつの有効 な手段と考えられる。

そこで今回は, 色彩と織り方の異なる様々な綿布に 対して生じた印象を調べ, それらの印象と個々の綿布 に対する好みとの間の因果的な結びつきを共分散構造 分析によって調べ，その因果的結びつきと好みの個人 
差との関係を探ることにした。

\section{2. 実 験}

\section{(1) 目 的}

織り方と織り系の配色の異なる綿布に対する好みを 評定させたときの個人差に注目し, 評定の個人差が, “好み”と他の印象との間の因果的な結びつきによって 左右されるのではないかという仮説を検証する.

（2）方 法

材料は赤 $(\mathrm{R})$, 黄 $(\mathrm{Y})$, 緑 $(\mathrm{G})$, 青 $(\mathrm{B})$, 紫 $(\mathrm{P})$, 白 (W), 黒 (Bk) の 7 色の系を, 縦系と横系にした 21 の 色の組み合わせからなる布である. なお, 各色のマン セル值は表 1 に示すとおりである，系は綿系で，太さ は 60-2, 織りの密度は緹 85 本/インチ, 横 70 本/イン チであり, 布の織り方は平織り, 綾織り $1 / 2$, ナナコ $2 /$ 2 , 綾織り $1 / 3$, アムンゼンの 5 通りである (図 1 ). 配 色条件 $21 \times$ 織り条件 5 の計 105 種類の布 $(260 \times 180$ $\mathrm{mm}$ ）を灰色の紙に貼りつけて刺激材料とした.

手続きとして, 被験者は D 65 蛍光灯照明下の明室 (刺激面の照度 $70 l \mathrm{x}$ ) で刺激材料を手にとり, 約 $30 \mathrm{~cm}$ の距離から眺め, 表 2 に示した 20 の印象評定項目に対 し “全然そう思わない”から“まったくそう思う”の 7 段階で評定した。被験者は男子 13 名, 女子 32 名の 計 45 名の心理学専攻の大学生で, 年齢は 18〜23 歳で ある。

\section{3. 結果および考察}

\section{3-1. 分析 1 （印象評定項目ごとの個人差の分析）}

それぞれの印象評定項目間で個人差の現れ方に差が あるかどうかを調べるため, 評定項目ごとに被験者ど うしの相関を求めた。表 2 に, 各印象評定項目におけ る個人間の相関係数の最小値と最大値, 中央值, 四分 位範囲を示した。これによれば“渋い”，“さわやか

表 1 織り系のマンセル値

Tab. 1 The Muncell color of the weaving thread.

\begin{tabular}{cc}
\hline 色 相 & マンセル値 \\
\hline 赤 $(\mathrm{R})$ & $7.5 \mathrm{R} 6.5 / 9$ \\
黄 $(\mathrm{Y})$ & $5 \mathrm{Y} 9.0 / 8$ \\
緑 $(\mathrm{G})$ & $10 \mathrm{GY} 7.0 / 8$ \\
青 $(\mathrm{B})$ & $2.5 \mathrm{~B} 7.0 / 8$ \\
紫 $(\mathrm{P})$ & $10 \mathrm{~PB} 6.0 / 4$ \\
白 $(\mathrm{W})$ & $\mathrm{N} 9.5$ \\
黒 $(\mathrm{Bk})$ & $\mathrm{N} 1.5$ \\
\hline
\end{tabular}

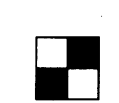

$\mathrm{a}:$ 平織り

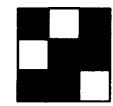

b: 綾織 $1 / 2$

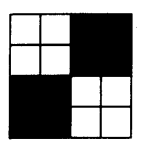

c：ナナコ $2 / 2$

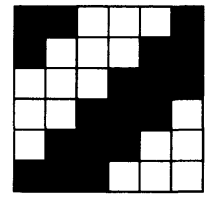

$\mathrm{d}:$ 綾織り $1 / 3$

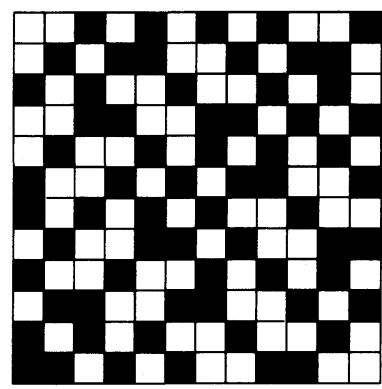

$\mathrm{e}:$ アムンゼン
図 1 実験で用いた布の織りのパターン

Fig. 1 The weaving patterns used in the experiment.

な”, “若々しい”などは最小の相関係数でも正の値と なっており，それぞれの綿布に対して全く反対の印象 をもつ被験者はいなかったことになり，比較的個人差 の少ない項目といえる。しかし，項目によっては相関 係数が負の值をとる被験者の組が多くみられたものも あった。特に, 今回問題にしている評価項目である“好 き”の場合，負またはゼロに近い相関を示す被験者の 組み合わせが非常に多く, 強い個人差がみられた。

\section{3-2. 分析 2}

（共分散構造分析による因果モデルの検討）

まず，各印象評定項目間の関連性をみるために，そ れぞれの綿布に対する被験者全員の平均評定值を各印 象評価項目ごとに求め, 因子分析（主因子法）を行っ た. 表 3 にバリマックス回転後の因子負荷量を示す. これによれば, 第 1 因子では “さわやかな”, “若々し い”，“好き”，“親しみやすい”などの因子負荷量が高 く,さわやかさと評価（好み）とが混じりあった因子 といえる.また，第 2 因子は “モダンな”，“都会的 な”, “織細な”, “洗練された”などの因子負荷量が高 く, 現代性因子と名づけることができょう. 第 3 因子 は“暖かい”，“冷たい” の因子負荷量が高いことから， 暖かさ冷たさ因子といえる。

第 1 因子のなかにさわやかさと評価（好み）に関す る項目が含まれたのは, 被験者の多くがさわやかな印 象の綿布を好んだためと思われる。しかし，たとえば 個人ごとに“さわやかな”と“好き”との関係を調べ ると, 両者の関係が薄かったり, 全く逆の関係をもっ たりする者もいることから（相関係数 0.2 以下の者は 
表 2 各形容詞における被験者間の相関係数の中央値, 四分位範囲, 最大值お よび最小值

Tab. 2 The median, the maximum and the minimum of correlation coefficients between subjects for each sensory evaluation word.

\begin{tabular}{l|c|c|c|c}
\hline \multicolumn{1}{c|}{ 評定項目 } & 中央値 & 四分位範囲 & 最小值 & 最大值 \\
\hline さわやかな & 0.63 & 0.21 & 0.15 & 0.88 \\
浊い & 0.62 & 0.20 & 0.06 & 0.88 \\
若々しい & 0.57 & 0.22 & 0.02 & 0.90 \\
やわらかい & 0.55 & 0.29 & -0.08 & 0.84 \\
清潔な & 0.49 & 0.23 & -0.14 & 0.85 \\
華やかな & 0.43 & 0.27 & -0.14 & 0.81 \\
かわいい & 0.38 & 0.27 & -0.23 & 0.86 \\
冷たい & 0.36 & 0.26 & -0.34 & 0.67 \\
落ち着いた & 0.35 & 0.35 & -0.37 & 0.83 \\
暖かい & 0.32 & 0.51 & -0.50 & 0.78 \\
ロマンチックな & 0.30 & 0.36 & -0.55 & 0.87 \\
個性的な & 0.24 & 0.22 & -0.55 & 0.62 \\
親しみやすい & 0.14 & 0.24 & -0.56 & 0.81 \\
都会的な & 0.14 & 0.25 & -0.62 & 0.75 \\
緎細な & 0.12 & 0.30 & -0.62 & 0.69 \\
洗練された & 0.12 & 0.30 & -0.63 & 0.69 \\
上品な & 0.07 & 0.32 & -0.64 & 0.75 \\
好き & 0.06 & 0.25 & -0.70 & 0.81 \\
ナチュラルな & 0.04 & 0.29 & -0.73 & 0.78 \\
モダンな & 0.03 & 0.38 & -0.75 & 0.80 \\
\hline
\end{tabular}

45 名中 7 名)，被験者全員がさわやかなものを好むと いうわけではないことが予想できる。また“モダンな” と“好き”との関連性を調べたところ，非常に高い相 関を示す者がかなりいた（相関係数 0.5 以上の者は 45 名中 20 名)。また，“冷たい”と“好き”とでは，顕著 な負の相関を示す者はあまりみられなかった（相関係 数 -0.5 以下の者は 45 名中 3 名).

以上より，綿布の好みを左右する印象としては，さ わやかさと現代性が考えられ，それらの印象と評価(好 み）の印象との因果関係のあり方により綿布に対する 最終的な評価の個人差が決定されるのであろうと予測 した. そこで，これらの印象間の因果モデルとして図 2 に示すような 6 つのモデルを想定した。なお，図中 のS, G, Hはそれぞれさわやかさ, 現代性, 評価の各 印象（潜在変数）を表し，k 1，k 5 などは各印象評定 項目の番号（観測変数，表 3 ）を表す。また，eは今 回取り上げた変数以外の要因, すなわち誤差要因を示 す.

モデル 1 では次のようなことを想定している，すな わち，綿布を見たときにまずさわやかさ $(\mathrm{S})$ の印象が 人間の内部で生じる。その印象が生じると“さわやか な：k 15”，“若々しい：k 3”という言語報告がなされ
表 3 バリマックス回転後の因子負荷量

Tab. 3 A factor loading matrix after varimax rotation.

\begin{tabular}{|c|c|c|c|c|}
\hline & 評定項目 & 第 1 因子 & 第 2 因子 & 第 3 因子 \\
\hline k 1 & 都会的な & 0.19 & 0.77 & 0.12 \\
\hline k 2 & 暖かい & 0.23 & 0.16 & 0.94 \\
\hline k 3 & 若々しい & 0.74 & 0.39 & 0.51 \\
\hline k 4 & 親しみやすい & 0.78 & 0.34 & 0.48 \\
\hline k 5 & モダンな & -0.04 & 0.90 & 0.28 \\
\hline k 6 & 清潔な & 0.82 & 0.47 & 0.27 \\
\hline k 7 & 渋い & -0.73 & -0.36 & -0.52 \\
\hline $\mathrm{k} 8$ & ロマンチックな & 0.61 & 0.56 & 0.50 \\
\hline k 9 & 好き & 0.71 & 0.54 & 0.30 \\
\hline $\mathrm{k} 10$ & やわらかい & 0.50 & 0.56 & 0.58 \\
\hline $\mathrm{k} 11$ & 冷たい & -0.15 & 0.01 & -0.85 \\
\hline $\mathrm{k} 12$ & ナチュラルな & 0.74 & 0.21 & 0.15 \\
\hline $\mathrm{k} 13$ & 落ち着いた & -0.55 & -0.33 & -0.63 \\
\hline $\mathrm{k} 14$ & 個性的な & -0.85 & 0.01 & -0.13 \\
\hline $\mathrm{k} 15$ & さわやかな & 0.81 & 0.48 & 0.27 \\
\hline $\mathrm{k} 16$ & 上品な & 0.35 & 0.75 & 0.04 \\
\hline $\mathrm{k} 17$ & 華やかな & 0.55 & 0.42 & 0.67 \\
\hline $\mathrm{k} 18$ & 洗練された & 0.36 & 0.86 & 0.11 \\
\hline k 19 & かわいい & 0.65 & 0.43 & 0.60 \\
\hline $\mathrm{k} 20$ & 緎細な & 0.37 & 0.82 & 0.15 \\
\hline
\end{tabular}


る.また,さわやかさ $(\mathrm{S})$ の印象と同時に, 現代性 $(\mathrm{G})$ の印象も生じる.現代性の印象が生じると“モダンな： $\mathrm{k} 5$ ”, “都会的な：k 1”という言語報告がなされる。そ して,さわやかさと現代性の印象は, ともに評価 $(\mathrm{H})$ 印象を引き起こす。そして, 評価印象が引き起こされ ると“好き：k 9”, “親しみやすい：k 4”という言語報 告がなされる。 また,さわやかさ印象と現代性印象と は互いに関連しあう。

モデル 2 では, さわやかさ $(\mathrm{S})$ 印象と評価 $(\mathrm{H})$ 印象 の間には因果的なパスは存在しないとするもので, そ の他はモデル 1 と同じである.モデル 3 は, さわやか さ $(S)$ 印象と現代性 $(G)$ 印象との間に因果的なパスを 想定しないもの, モデル 4 は, 現代性 $(G)$ 印象と評価 (H)印象との間には因果的なパスはなく, 現代性 $(G)$ 印象がさわやかさ $(\mathrm{S})$ 印象を引き起こし, そのさわや かさ (S) 印象が評価 $(\mathrm{H})$ 印象を引き起こすとするもの, モデル 5 は, さわやかさ $(\mathrm{S})$ 印象だけが評価 $(\mathrm{H})$ 印象 と結びつくというもの, モデル 6 は, 現代性 $(G)$ 印象 だけが評価 $(\mathrm{H})$ 印象と結びつくというものである.

以上， 2 つあるいは 3 つの潜在変数 (印象) と 4 つ ないしは 6 つの観測変数（形容詞）からなる 6 つの因
果モデルを想定し, 個々の被験者がどのモデルに適合 するのかを共分散構造分析により調べた。計算は SAS のCALIS プロシジャを用いて行った。

なお, 今回はモデルの単純化のために, それぞれの 潜在変数 (印象)に2つずつの観測変数（評価項目） を配した。

被験者ごとに 6 つのモデルに関して計算を行い, 最 適なモデルを選択するのに有効といわれる AIC (Akaike's Information Criterion) の值が最小で, し かもモデル適合度 AGFI (Adjusted Goodness of Fit Index）の值が 0.8 以上のものを最適モデルとして採 用したところ，モデル 1 があてはまった者は 1 名, モ デル 2 は 0 名, モデル 3 は 1 名, モデル 4 は 4 名, モ デル 5 は 8 名, モデル 6 は 11 名で, 被験者 45 名中 25 名がモデル 2 を除くいずれかのモデルに適合した。

また因果係数は, いずれも高い正の值をとった，図 2 の数值はそれぞれの因果係数である.モデル 1 と 3 は適合した被験者が 1 名しかいなかったので, それぞ れ 1 名の結果を示したが，モデル 4, 5,6 に関しては, それぞれ該当する被験者の因果係数の平均值を示した.
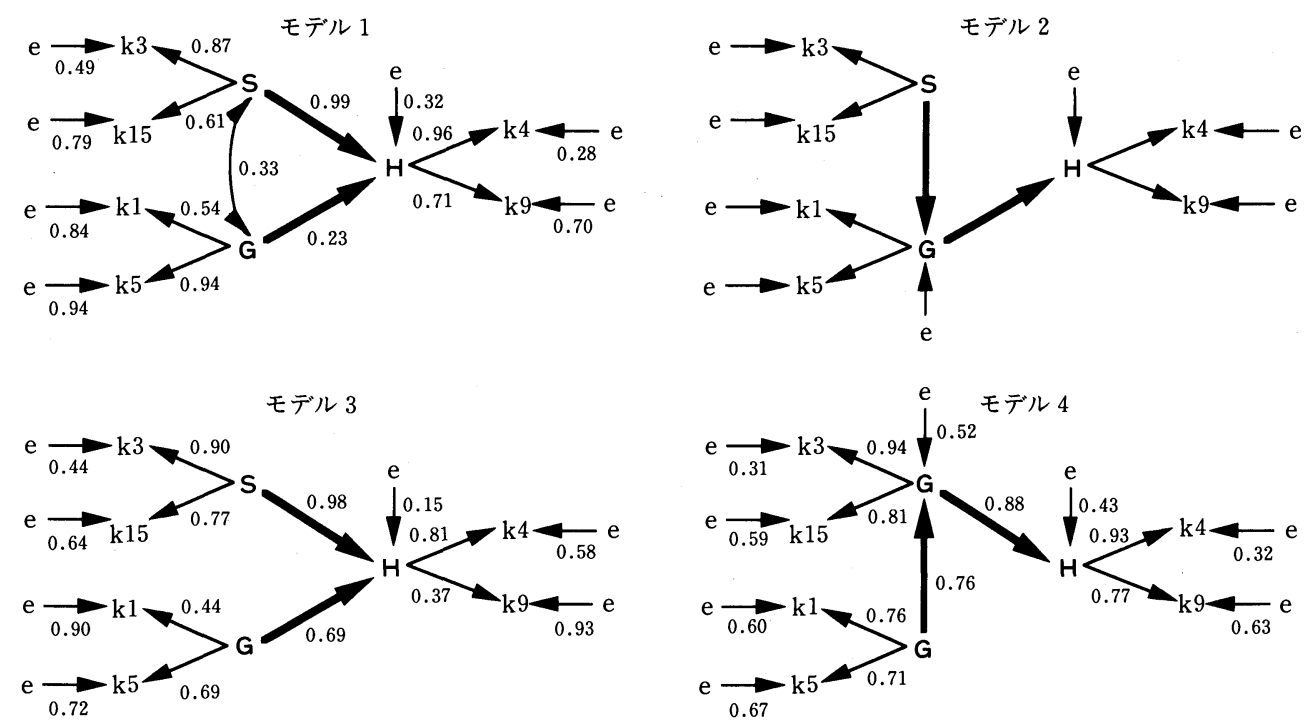

モデル 5

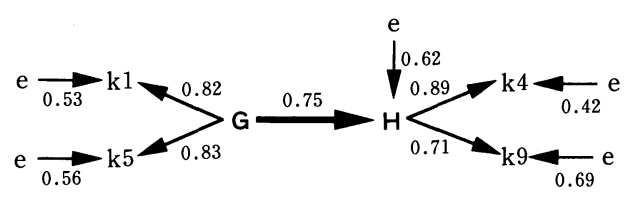

モデル 6

図 2 想定した因果モデル

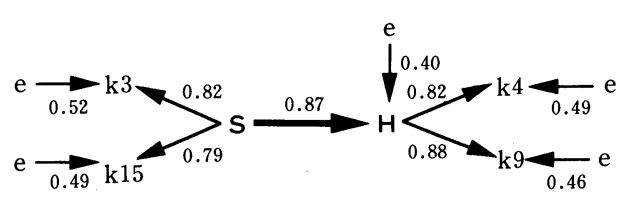

Fig. 2 Expected causal models. 
3-3. 分析 3 (適合するモデルと綿布の好みとの 関連性の分析）

分析 2 により適合するモデルが被験者によって異な ることが明らかにされたが, 適合するモデルの違いが, 綿布の好みの違いを引き起こしていると考えてよいの であろうか.

これを検討するために, 105 枚の綿布に対する各被 験者の好みのデー夕（評価項目の好きの評定値）から 被験者間のユークリッド距離を求め, その距離デー夕 をもとにしてクラスター分析（ウォード法）を行い,

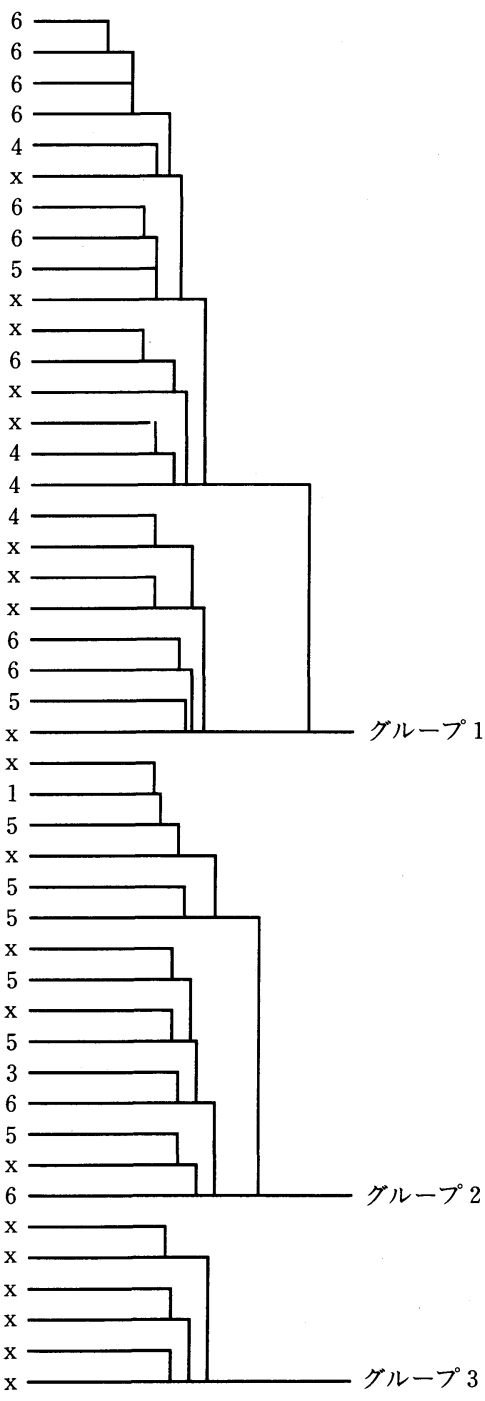

図 3 クラスター分析によって得られた樹状図

Fig. 3 A dendrogram obtained from a cluster analysis of subjects.
被験者をグループ分けしたところ，3つのグループに 分かれた（図 3 )。

図 3 中の数值は各被験者に適合したモデルの番号で, $\mathrm{x}$ は適合するモデルがなかった被験者である.図 3 よ り，モデル 1 と 3 に適合した各 1 名の被験者はいずれ も第 2 グループに属し，モデル 4 に適合した被験者 4 名は全員第 1 グループに属した。 また，モデル 5 に適 合した被験者 8 名のうち, 第 1 グループに属したのは 2 名だけで, 残りの 6 名は全員第 2 グループに属した. モデル 6 に適合した被験者 11 名中 9 名が第 1 グルー プに属し, 残りの 2 名は第 2 グループであった。 また, 第 3 グループに属した 5 名は, いずれもどのモデルに も適合しなかった。

以上より, モデル 4 と 6 に適合した被験者は第 1 グ ループに, モデル $1,3,5$ に適合した被験者は第 2 グ ループに属する傾向があることが明らかになった。

ここで図 2 をみると, モデル $1,3,5$ はいずれも現 代性 $(\mathrm{G})$ と評価 $(\mathrm{H})$ との間に直接の因果のパスを想定 しており, その意味でこれらのモデルには共通点があ るといえる. モデル 1 に適合した 1 名の結果をみると, 現代性と評価とを直接結ぶ因果係数が正の值をとって おり, モデル 5 のそれも正の值であったことから, 両 者は共通した因果的特徵をもっているといえる. しか し, モデル 3 に適合した者の場合は, その值が負にな っており，必ずしも共通の特徵とはいいがたい結果と なっている.

また，モデル 4 とモデル 6 は現代性と評価との間に 直接のパスを想定せず, さわやかさと評価との間に直 接の因果関係を想定しているところが共通点といえる. さわやかさと評価との間の因果係数を比較しても, 両 者はいずれも高い正の值をとっており，ここでも共通 点が見いだせる。

以上のことから，印象どうしの因果的な結びつきと 布に対する好みとの間には, 完全とまではいかなくと も，ゆるい関係があるといえるのではないかと思われ る.

次に, これら 3 つのグループに属する被験者の好み の傾向を調べるために, グループごとに個々の綿布に 対する好みの平均值を求めた. 図 4 に各グループごと の綿布に対する好みの平均評定值を示す。

グループ 1 はモデル 4 と 6 に適合した被験者が多く 含まれるグループであるが，ここでは織りの違いは評 価にはほとんど影響せず, 主に系の配色によって評価 が左右された (図 4 上). 彼らは, 赤と白, 黄と白, 緑 と白, 紫と白というように，片方に白系が入った布を 好む傾向があった．これらはいずれも淡い色調に見え る. さらに, 赤と黄, 黄と緑, 黄と青, 青と紫なども 

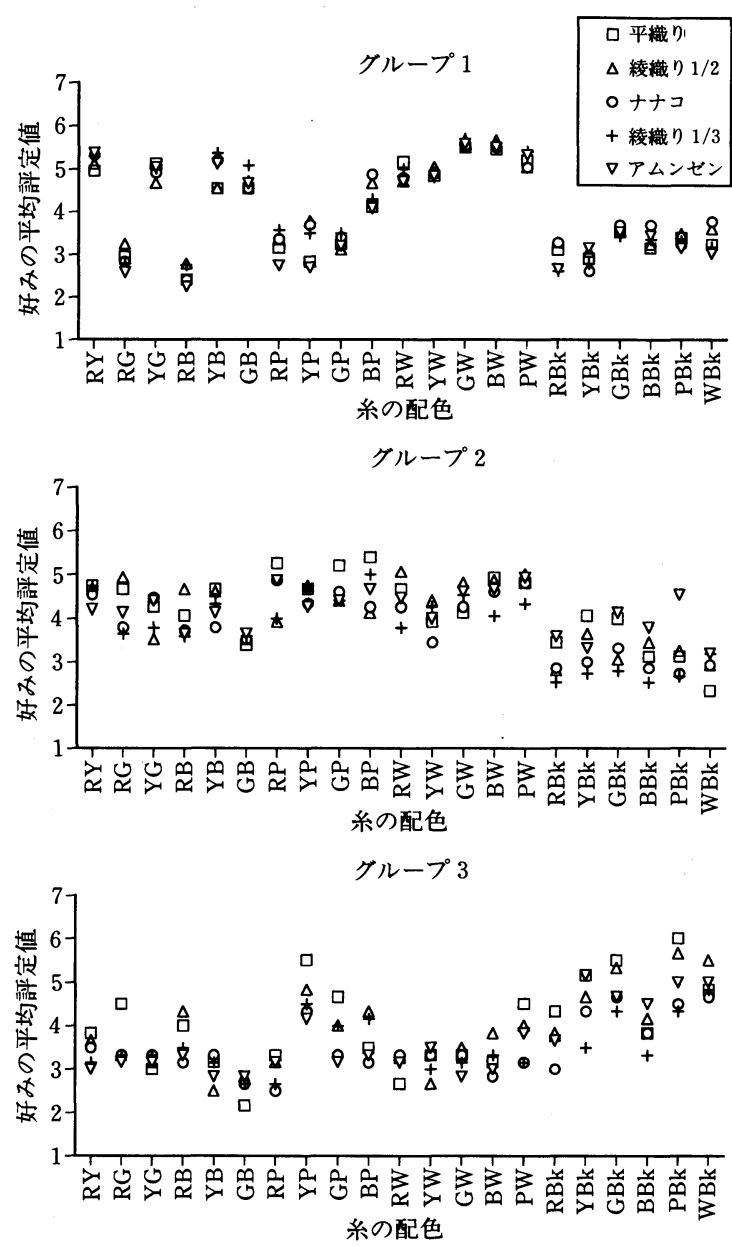

図 4 各グループにおける布の好みの平均評定値

Fig. 4 Average preference value for cloths in each group.

高い評価を得た。一方, 赤と黒, 黄と黒, 緑と黒, 青 と黒, 紫と黒, 白と黒という黒系の入った 6 枚の布, さらには赤と緑, 赤と青, 赤と紫, 黄と紫, 緑と紫な どの評価は低かった. 以上より,グループ1はパステ ル調の明るい布を好むグループといえる。

グループ 2 は, 現代性と評価との間に直接の因果関 係を想定した点で共通するモデル $1,3,5$ に適合した 被験者が多く含まれていたグループであるが, グルー プ1に比べると織りの影響が少し強く現れた。全体に 綾織り $1 / 3$ の評価が低い傾向がみられ, 系の配色によ って好まれる織り方も若干異なる傾向もみられた。系 の配色では, 黒系が入った 6 枚の布に対する評価はグ ループ1の場合と同様に低かったが, その他の配色に 関しては色の違いはあまり顕著に現れなかった。グル
ープ 1 と比較すると, グループ 1 で評価の低かった赤 と緑, 赤と青, 赤と紫, 黄と紫, 緑と紫に対する評価 は, 他の配色のそれとあまり差がなく, 結果として, それらの評価はグループ1よりも相対的に高くなった (図 4 中). 以上より,グループ 2 は紫の糸が入り, や や個性的な，繊細な色調の布を好むグループといえる． グループ 3 には, いずれのモデルにも適合しない被 験者のみが属していた.グループ1に比べると織りの 効果が比較的みられ, 全体的に平織りが好まれる傾向 があった.また,グループ1とグループ 2 のいずれに おいても評価の低かった黒系が入った布に対する評価 が比較的高く, 黄と紫の布の評価も高かった. 後者は グループ1では評価の低かったものである．また，グ ループ 1 で特に評価の高かった白系の入った布に対し ては，全体的に評価が低かった（図 4 下）。以上より, グループ 3 は全体的に落ち着いた地味めの布を好むグ ループのようである.

\section{3-4. 分析 4 （グループ 3 に属する被験者のため} の因果モデルの再構築とその検討）

グループ 3 に属する被験者は, 初めに想定した $6 \supset$ のモデルのいずれにも適合しなかった．その理由はい くつか考えられるが, 彼らのなかではさわやかさと現 代性が評価の原因にはなっていないということも理由 のひとつとして考えられる. そこで, グループ 3 に属 する被験者が地味で落ち着いた配色の布を好む傾向が あったことから,さわやかさ (S)のかわりに落ち着き (O)印象を原因として加え，これまでと同様の因果分 析を行った。その際, 落ち着き $(\mathrm{O})$ 印象と関連する観 測変数として, “渋い：k 7”と“落ち着いた： $\mathrm{k} 13$ ”を 取り上げた。

分析の結果, 1 名がモデル 7 に, 他の 1 名がモデル 8 に適合することがわかった(図 5 ). しかし, 残りの 4 名は今回の分析でも適合しなかった。モデル 7 は落 ち着き $(O)$ 印象と現代性 $(G)$ 印象とが評価 $(H)$ 印象の 原因となっており，しかも，両者の間には関連性があ るというもの, またモデル 8 は落ち着き $(\mathrm{O})$ 印象のみ が評価 $(\mathrm{H})$ 印象の原因になっているというものである. なお, 他の 2 つのグループに属するいずれの被験者も, モデル 7 や 8 には適合しなかった。

\section{4. むすび}

潜在変数として,さわやかさ, 現代性, 評価の 3 つ を取り上げ, さわやかさと現代性とが, 評価（好み） とどのように結びついているのかを, 被験者ごとに調 べた.その結果, 45 名のうち 25 名がこれらのモデルの 

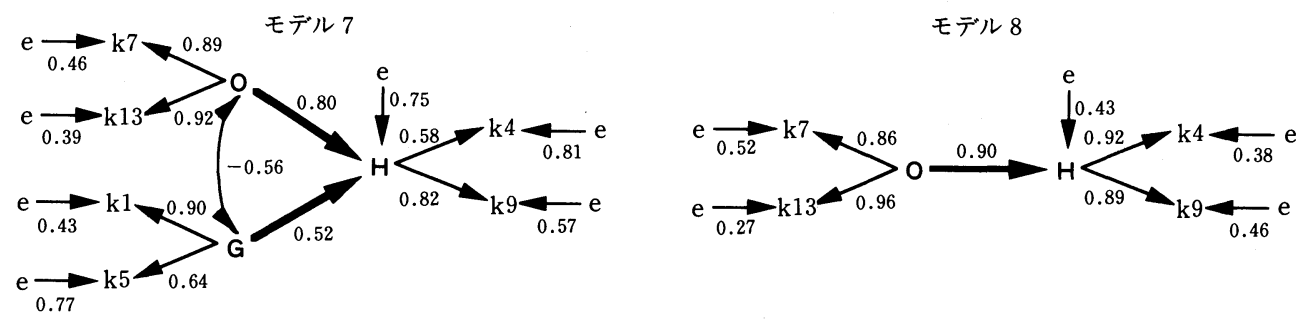

図 5 新たに加えた因果モデル

Fig. 5 Additional causal models.

いずれかにあてはまった。 また，さわやかさ印象のか わりに落ち着き印象を潜在変数に加え, 一連の因果分 析でいずれのモデルにもあてはまらなかった被験者の 再分析を行ったところ, 新たに 2 名の被験者が, 新た

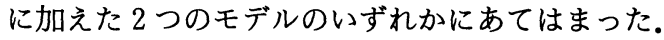

そして，布に対する好みとこれらの潜在変数間の関 係とに関連性があることが明らかにされた。つまり， 現代性と評価との間に直接のパスを想定せず, さわや かさと評価との間に直接の因果関係を想定しているモ デル 4 とモデル 6 に適合した被験者の多くは，好みに よる分類ではグループ 1 に属し, 明るく淡い色調の布 を好んだ。また，現代性と評価との間に直接の因果関 係を想定した点で共通するモデル $1,3,5$ に適合した 被験者の多くはグループ 2 に属し，紫の糸が入り，や や個性的な繊細な色調の布を好む傾向があった。そし てグループ 3 は，黒い系の入った渋い色調の布を好む グループであるが，そこに属する 6 名の被験者はいず れのモデルにもあてはまらず，さわやかさ印象に代え て落ち着き印象を潜在変数に導入したところ，2名の 被験者が新たなモデルに適合した。

以上が今回の結果の概要であるが, これらから内部 印象どうしの因果的な結びつきのあり方が好みの個人 差を左右しているのではないかという当初の仮説は, おおむね支持されたといえる。
好みの個人差を調べる方法としては，三相因子分析 や多次元展開法, 重回㷌分析など, 様々な方法が考え られるが，共分散構造分析は潜在変数どうしの因果関 係を直接探ることができ, 最終的な評価へといたる内 部印象どうしの因果関係を明確に意識化できない人に も適用できるという点で，優れた方法であるといえる。 今回明らかにされた潜在変数どうしの因果的な結び つきが，人間の内部での感性情報処理の道筋をそのま ま表現していると結論づけることは危険であるが，こ のような統計的な処理結果から，直接観察することの できない人間の内部の情報処理過程をある程度推測で きるのではないかと思われる。

この研究は, 平成 4 年度〜 6 年度文部省科学研究費 補助金（課題番号 04236105）によるものである．実験 の準備, 実施にあたり, 本間義満氏（愛知県尾張緎維 技術センター), および柴田晃伸氏(愛知県三河㵶維技 術センター）より多大なご協力をいただきました。両 氏に深く感謝いたします。

\section{参考文献}

1）豊田秀樹，前田忠彦，柳井春夫：原因をさぐる 統計学一共分散構造分析入門一, 講談社, 1992. 